\title{
PREVALENCE OF GASTROINTESTINAL PARASITISM INFECTIONS IN CATTLE OF BASS KABYLIE AREA: CASE OF BEJAIA PROVINCE, ALGERIA
}

\author{
Lotfi Moussouni ${ }^{1}$, Mokhtar Benhanifia $^{2}$, Mokhtar Saidi $^{3}$, Abdelhanine Ayad $^{1}$ \\ ${ }^{1}$ Department of Biological Sciences of Environment, Faculty of Life and Nature Sciences, \\ University A. Mira, 06000, Bejaia, Algeria \\ ${ }^{2}$ Department of Agricultural Sciences, Faculty of Life and Nature Sciences, \\ University M. Stambouli, 29000, Mascara, Algeria \\ ${ }^{3}$ Department of Agronomic and Biotechnological Sciences, Faculty of Life and \\ Nature Sciences, University H. Benbouali, 02000, Chlef, Algeria
}

Received 7 August 2017; Received in revised form 5 December 2017; Accepted 12 December 2017

\begin{abstract}
The objective of this study was to determine the prevalence, identification of species and the dynamics of gastrointestinal (GI) parasites during humid and dry seasons in local cattle of different ages. The study was carried out in the Province of Bejaia, Algeria from December 2013 to June 2014. A total of 143 fecal samples were collected from different cattle herds. Fecal samples were visually examined then observed using flotation and sedimentation microscopic techniques. Eggs and worms were identified according to standard procedures. $63 \%$ of the cattle examined were found positive with one or more parasite species. Our results revealed that the eggs of Eimeria spp. are predominant (43.87\%) followed by Strongylus spp. (30.32\%) and Fasciola hepatica (12.25\%). Eggs of Strongyloides papillosus, Moniezia benedeni, Paramphistomum daubneyi. and Toxocara vitulorum represent $1.29 \%, 1.93 \%, 1.93 \%$ and $6.45 \%$, respectively. There is a significant difference between the sex of the animal and the prevalence rate of Strongyle spp. and Eimeria spp. $(P<0.01)$. As for the body condition score, there is a statically significant $(P<0.01)$ difference between the prevalence rate of GI parasite and the nutritional status of cattle. In conclusion, our preliminary investigation demonstrated highly prevalent and that abundance of the polyparasitism nature of the disease in Bass Kabylie area. Also, there was a relationship between the distribution of GI parasitism in cattle and the factors analyzed (body condition score, age and sex). Further studies are need for planning future research and to design rational and sustainable locally GI parasites control programmes.
\end{abstract}

Key words: prevalence, gastrointestinal, parasitism, cattle, Bass Kabylie

\section{INTRODUCTION}

In Algeria, the livestock sector observed a singular growth rate in recent years. The national herd, consisting of all types of ruminants, exceeds 34 million heads including 28.9 million sheep, 4.9 million goats and 1.9 million cattle (1). The larger part of the bovine population is concentrated in the

Corresponding author: Prof. Dr. Abdelhanine Ayad, $\mathrm{PhD}$ E-mail address: hanine06@gamil.com

Present address: Department of Biological Sciences of Environment, Faculty of Life and Nature Sciences, University A. Mira,

06000, Bejaia, Algeria

Phone: ++213.772722595

Copyright: (C) 2018 Moussouni L. This is an open-access article published under the terms of the Creative Commons Attribution License which permits unrestricted use, distribution, and reproduction in any medium, provided the original author and source are credited.

Competing Interests: The authors have declared that no competing interests exist

Available Online First: 29 January 2018

Published on: 15 March 2018

https://doi.org/10.2478/macvetrev-2018-0010 northern region of the country, mainly in Kabylie (43.043 heads, $2.25 \%$ ).

Domestic ruminants raised on pasture are infested by gastrointestinal helminthes. The parasitic infection is a serious constrain to health and productivity of the livestock in cattle, sheep and goats $(2,3)$. The negative impact of helminthic infections on livestock productivity in some countries has been established (4). In dairy cattle, parasitic infections reduce milk yield by 1.2 to $2.2 \mathrm{~kg} \mathrm{milk} / \mathrm{cow} / \mathrm{day}$ (5). In addition, reproductive performance, loss in body weight and digestive disturbances have been reported $(6,7)$.

Many studies reported that the GI parasite infections of ruminants are mostly caused by nematodes, cestodes and trematodes (8). However, the types of disease and parasites outbreaks among animal populations are greatly influenced by the 
geographic location and seasons (9). Moreover, climatic conditions like ambient temperature and rainfall patterns have great influence on the pasture and the food resources availability cycle throughout the year (9).

The epidemiology of gastrointestinal parasites infections (GIP) in cattle has been well documented in several countries which helped improve helminths control, animal performance and decrease in production losses $(6,9,10)$.

Constituting a database of internal parasites and disease surveillance is extremely important in the management of cattle to achieve improved production. In Algeria, especially in the Bass Kabylie region, there are a few reports and unstructured data is available on the gastrointestinal parasite of bovine. In this study, we determine the prevalence, the species and the dynamics of gastrointestinal parasites during the humid and dry seasons in local cattle of different ages.

\section{MATERIAL AND METHODS}

\section{Study area}

The study was carried out in the Province of Bejaia, Algeria $\left(36^{\circ} 43^{\prime} \mathrm{N}, 5^{\circ} 04^{\prime} \mathrm{W}\right)$ (Fig. 1). It has an area of 326,826 kilometer square $\left(\mathrm{km}^{2}\right)$ with a bovine population of 43,000 . The topography of the area is predominated by mountains separated by the Soummam valley. With regards to the climate, it is part of the Mediterranean region. The winter rainfall in the region ranges from $600-1000 \mathrm{~mm}$. The mean maximum summer temperature reaches $30.9{ }^{\circ} \mathrm{C}$ (September) and the mean minimum winter temperature falls to $8.8{ }^{\circ} \mathrm{C}$ (February). The vegetation is mainly composed of several species of trees and natural and cultivated herbs.

\section{Animals and sampling}

The study was conducted from December 2013 to June 2014. One hundred and forty-three fecal samples were collected from different cattle herds. Five grams of fecal samples were collected from the animal rectum directly into clean polyethylene disposal bags using a hand glove (11). Body condition scores (BCS) of animals were recorded. Scores were given by the same researcher based on a 1 to 5 scales (12). The age of the animals ranged between 2 months and over 3 years with mixed parity. Animals were selected randomly and they did not receive any anthelmintic treatment.

\section{Fecal examination}

Parasitological examinations were carried out using standard methods at the Laboratory of Animal Biology, University of Bejaia. Fecal samples were visually examined then observed using flotation and sedimentation microscopic techniques (11).

Fecal eggs were counted in fresh fecal sample in a McMaster slide using saturated saline $(\mathrm{NaCl})$ solution as flotation liquid $(\mathrm{d}=1.18)$. The number of eggs per gram of feces was obtained by multiplying the total number of eggs counted in the two squares of

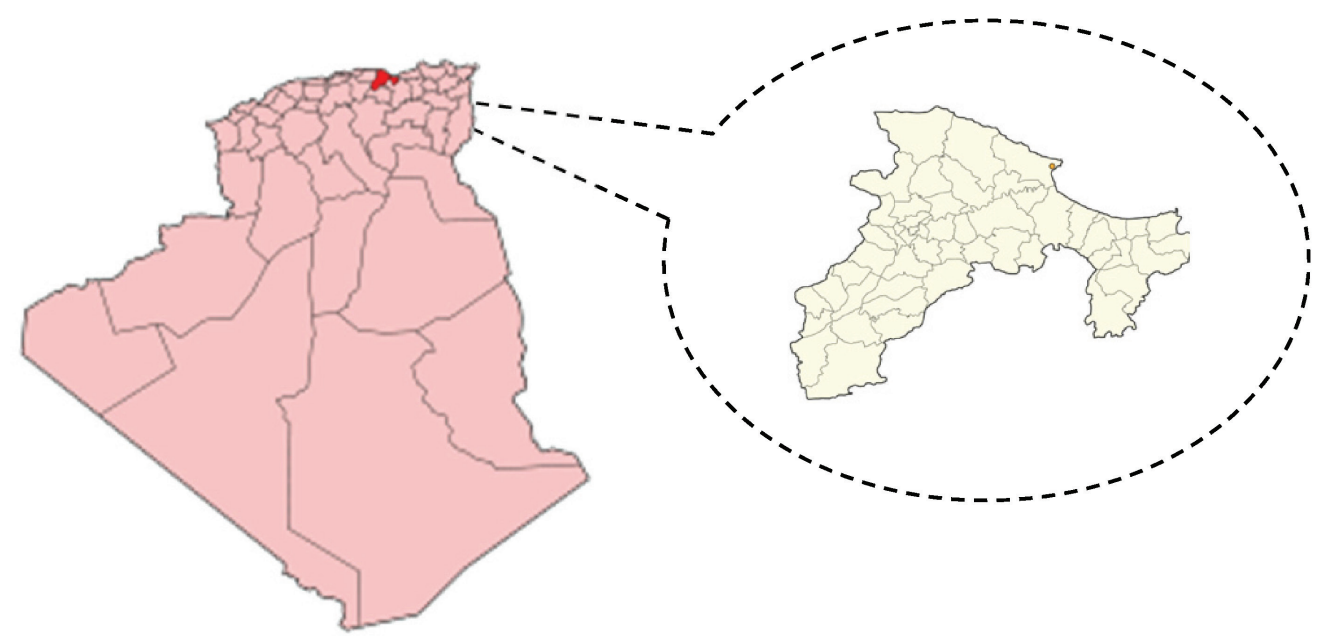

Figure 1. Map of the study of Bejaia province, Algeria 
the counting chambers of the McMaster slide by the dilution factor of 50 (13). The results are expressed as eggs per gram of feces (EPG) or oocytes per gram of feces (OPG). Eggs were identified on the basis of their morphological features (14). Species identification and determination of worm were carried out according to standard procedures.

\section{Statistical analysis}

Statistical analyses were carried out using the XL Stat program (version 14.5.03). The prevalence was calculated as the ratio between the number of animals having the parasites and the number of surveyed cattle. The data $( \pm \mathrm{SD})$ was expressed as percentage $(\%)$. The egg numbers were analyzed using gender (8 male and 135 female), age (13 young: $\leq 1$ year aged; 130 old: $>1$ years aged) and body corporal score (21 Thin: 1-2; 122 obese: $2.5-5$ ) as factors of variation. The statistical analysis was performed using variance analysis (ANOVA). The values were statistically different when the $P$-value was $<0.05$.

\section{RESULTS}

The monthly rainfall and mean temperature during the period of study are presented in Table 1 .

Sixty three percent of the 143 cattle examined were found positive with one or more gastrointestinal parasites. Species of gastrointestinal parasites (GI) are found after examination of fecal samples (Fig. 2). The microscopic observation revealed that the eggs of Eimeria spp. are predominant (43.87\%) followed by Strongylus spp. (30.32\%) and Fasciola hepatica (12.25\%). Eggs of Strongyloides papillosus, Moniezia benedeni, Paramphistomum daubneyi and Toxocara vitulorum represent $1.29 \%$, $1.93 \%, 1.93 \%$ and $6.45 \%$, respectively.

The monthly overall average eggs burden ranged from $2.78 \%$ and $0 \%$ in December to $64.28 \%$ and 21.43 in June for Strongyle spp. and Strongyloides papillosus, respectively (Fig. 3). Whereas, it varied from $64.28 \%$ in December to $2.78 \%$ in June for oocystes Eimeria spp. The highest burden was recorded in Fasciola hepatica in May 37.71\% and the lowest in December and January. The highest burden for Toxocara vitulorum and Moniezia benedeni was observed in May (28.57\% and 14.28\% respectively), while for Paramphistomum daubneyi the only burden was found in June (5\%).

The results of relationships between age, sex, body score and GI parasites of cattle are shown in Table 2. Prevalence rates of Strongyle spp., Toxocara vitulorum, Fasciola hepatica, Strongyloides papillosus and Eimeria spp. in young animals $(\leq 1$ year old) was higher than in old animals $(\geq 1$ year old). Significant difference is recorded between the age of animal and the prevalence rate of two GI species namely Strongyle spp. and Eimeria spp.

Table 1. Annual rainfall and temperature data of the Bejaia area (Algeria) during the period 2013-2014

\begin{tabular}{lcc}
\hline & $\begin{array}{c}\text { Temperature } \\
(\text { Min-Max) }\end{array}$ & $\begin{array}{c}\text { Rainfall } \\
(\mathbf{m m})\end{array}$ \\
\hline January & $13.9(9-18.8)$ & 84.56 \\
February & $13.3(8.3-19.4)$ & 56.64 \\
March & $13(8.6-17.5)$ & 138.17 \\
April & $16.9(11.2-22.6)$ & 17.27 \\
May & $18(13-23.1)$ & 10.16 \\
June & $22.4(17.2-27.17)$ & 66.8 \\
July & $24.1(19.4-28.8)$ & 0.76 \\
August & $25.8(21.2-30.4)$ & 1.27 \\
September & $25.9(21-30.9)$ & 6.1 \\
October & $22(17-27.1)$ & 76.21 \\
November & $18.7(13.8-23.7)$ & 9.15 \\
December & $13.4(9.1-17.7)$ & 262.89 \\
\hline
\end{tabular}




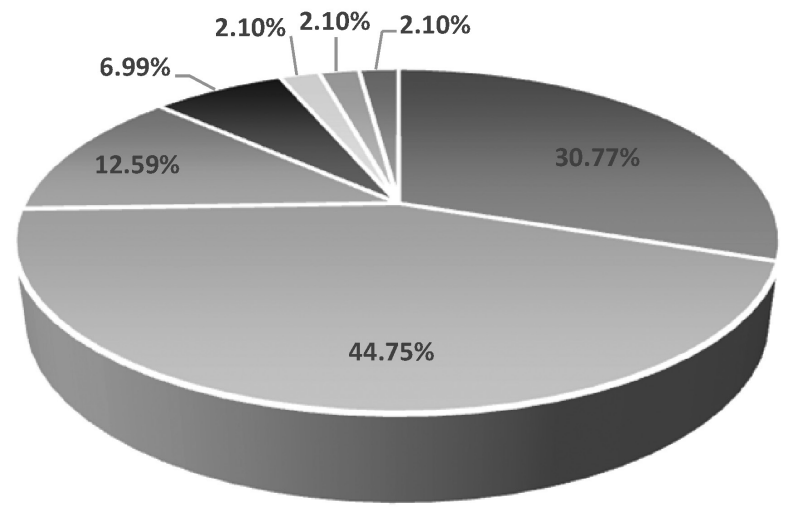

- Strongyle

- Eimeria spp.

- Fasciola hepatica

- Toxocara vitulorum

Strongyloides papillosus

- Paramphistomum daubneyi

- Moniezia benedeni

Figure 2. Prevalence of various gastrointestinal parasites of cattle in the Bejaia province

$(\mathrm{P}<0.01)$. In contrast, prevalence rates of Moniezia benedeni and Paramphistomum daubneyi in young animals $(\leq 1$ year old) was lower than old animals ( $\geq 1$ year old). No significant difference between prevalence rate and animal age was observed.

Except the Eimeria spp. species, all prevalence rates of GI parasites in male cattle higher than female cattle. However, there is a significant difference between the sex of animal and the prevalence rate of Strongyle spp. and Eimeria spp. $(\mathrm{P}<0.01)$.

As for the body condition score, there is a statistically significant $(P<0.01)$ difference between the prevalence rate of GI parasite and the nutritional status of cattle. Note that thin animals (under 2) were more infested with GI parasites than obese animals (above 2.5).

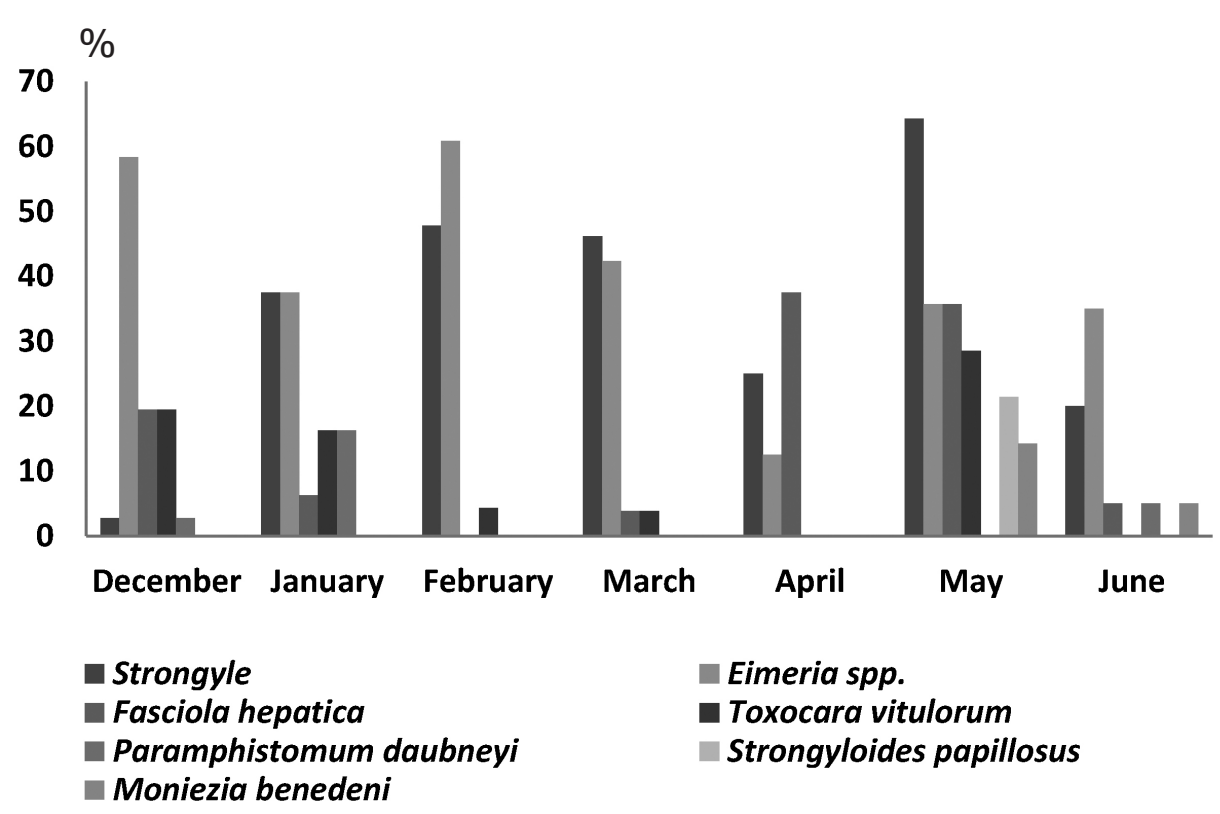

Figure 3. Seasonal variation in proportions of gastrointestinal parasite of cattle during the humid and dry period 
Table 2. Relationship between different factors (age, sex and body score) and gastrointestinal parasite of cattle in Bejaia province. Age (young: $\leq 1$ year aged; old: $>1$ years aged), sex (male and female), body corporal score (thin: 1-2; obese: 2.5-5). * Values with similar superscripts in the same factor differ statistically at the same parasite $(\mathrm{P}<0.01)$

\begin{tabular}{lcccccc}
\hline & \multicolumn{2}{c}{ Age } & \multicolumn{2}{c}{ Sex } & \multicolumn{2}{c}{ Body Score } \\
\hline & Young & Old & Male & Female & Thin & Obese \\
\hline Strongyles spp. & 6 & 38 & 4 & 40 & 7 & 35 \\
& $(46.15 \%)$ & $(46.91 \%)$ & $(50 \%)^{*}$ & $(29.62 \%)^{*}$ & $(38.09 \%)^{* *}$ & $(29.50)^{* *}$ \\
Eimeria spp. & 7 & & & & 5 \\
& $(43.85 \%)$ & $(53.84 \%)$ & $(19.04 \%)^{*}$ & $(44.44 \%)^{*}$ & $(33.33 \%)^{*}$ & $(45.08 \%)^{*}$ \\
Fasciola hepatica & 2 & 16 & 1 & 17 & 1 & 17 \\
& $(9.52 \%)$ & $(12.30 \%)$ & $(25 \%)^{*}$ & $(12.59 \%)^{*}$ & $(4.76 \%)^{*}$ & $(13.92 \%)^{*}$ \\
Toxocara vitulorum & 0 & 10 & 1 & 9 & 2 & 8 \\
Strongyloides papillosus & $(0 \%)$ & $(7.69 \%)$ & $(12.5 \%)$ & $(6.67 \%)$ & $(9.52 \%)$ & $(6.55) \%$ \\
& $(6.69 \%)$ & $(1.53 \%)$ & $(12.5 \%)$ & $(1.48 \%)$ & $(14.28 \%)$ & $(0 \%)$ \\
Paramphistomum daubneyi & 0 & 2 & 1 & 3 & 0 \\
& $(0 \%)$ & $(2.30 \%)$ & $(0 \%)$ & $(2.22 \%)$ & $(4.76 \%)^{*}$ & $(1.63 \%)^{*}$ \\
Moniezia benedeni & 1 & 2 & 1 & 2 & 1 & 2 \\
\hline Positive animals & $(7.69 \%)$ & $(1.53 \%)$ & $(12.5 \%)$ & $(1.48 \%)$ & $(14.76 \%)$ & $(1.63 \%)$ \\
\hline
\end{tabular}

\section{DISCUSSION}

Helminth infections in ruminants are recognized as a major constraint to livestock production. Usually, infections are subclinical with significant economic losses due to both mortality and reduced productivity of animals $(15,16)$. The present study revealed that the cattle herds in the Bass Kabylie region (Algeria) suffers from a wide variety of GI helminth infestation. Sixty three percent of the cattle were infested with one or more GI parasite species. Prevalence of GI helminth has been reported ranging from 0.72 to $67 \%$ in domestic animals from various parts of the world $(10,17)$. The epidemiology of GI parasites infections in livestock varies depending on the prevailing climatic conditions and management practices.

Proportion of gastrointestinal helminthic within the studied population clearly indicated heavy parasitic burden dominated by Strongles spp. Higher prevalence of helminth infections is probably caused by more frequent exposure to pasture contamination. The observed high prevalence in May might be due to favorable environmental conditions such as humidity and temperature. In contrast, the low prevalence in January may be due to hypobiosis. In our study the dry period is in June, and the egg excretion peak of digestive strongyles is reached in July and August. In 2012, Boucheikhchoukh (18) recorded prevalence of strongyles similar to our results (31.1\%). Other researchers have reported a low prevalence of $17.7 \%$ (19) and a higher one of $50.75 \%$ (20). As mentioned before, other studies reported prevalence of GIP ranging from 0.72 to $67 \%$ (10, 17). The rate of helminth infestation in cattle varies in different country. This could be ascribed to a variety of factors like grazing habits, level of education of the farmers, livestock management and the anthelmintic used (21). Temperature and humidity constitute crucial factors which greatly influence the life cycle of the parasite and the transmission of endoparasites. Indeed, in agreement with our observations, Fuentes et al. (22) demonstrated that the season played a significant role in determining helminthes community species rate in cattle.

In general, the infestation intensity of strongyloidiasis and toxocariasis exhibit a low dominance in the area of our investigation. The prevalence of Strongyloides papillosus observed in cattle was very low compared to the results reported by Achi et al. (19) (7\%). Toxocariasis is a very rare disease recorded in bovines because the parasitic disease often affects the very young (23). Our result is the only case of parasitosis 
indicated in Algeria (Bass Kabylie) with a rate of $6.45 \%$. Strongyloidiasis remains discrete until May, and then a considerable prevalence of $21.43 \%$ is recorded in June. According to Alcaraz et al. (24), the most favorable conditions for the development of the parasite are a temperature above $20^{\circ} \mathrm{C}$ and a high precipitation extent ensuring high level of humidity. Note that a single case of strongyloidiasis was found in the humid highland (Boukhlifa). In contrast, toxocariasis is not really influenced by the climatic conditions, but it mainly affects young animals (25). However, we have few positive fecal samples from the young animals in presented study.

The results of the prevalence of fascioliasis are less significant compared to other reports $(18,19,26)$. Furthermore, the results reported by Bendiaf (27) were similar (13.2\%) to our findings. In contrast, a lower rate of infected animals (6.5\%) has been recorded in the Northeast Algeria, case of Constantine area (28). The prevalence of fasciolosis has substantially progressed during the first months of the study to achieve a high rate of $35.71 \%$ in May. It is then significantly reduced to a rate as low as $8.33 \%$ in June. The epidemiology of fascioliasis is related to the exposure of cattle to the risk of ingestion of metacercariae (29). In our research, it corresponds to the pasturing and ingestion of metacercariae from cercariae released trans-wintering snails. This contamination in spring period is responsible for so-called summer Fasciolosis, which explains the presence of a high prevalence in April and May.

The prevalence of paramphistomosis in the Bass Kabylie region is highly comparable to those reported by Achi et al. (19) (12.1\% vs. $1.93 \%$ and $6.4 \%$ vs. $1.93 \%$, respectively). However, our results are very similar to those recorded by Mekroud et al. (28). This discrepancy in the prevalence could be related to many factors such as variable climatic conditions, habitats and age. This infection monitoring revealed two infestation peaks of $6.25 \%$ and $8.23 \%$ in December and March, respectively. In 2010, Lotfy et al. (30) observed the same epidemiological features. However, Paramphistomum daubneyi metacercaria leave the mollusks when the temperature drops (31). Therefore, the contamination with Paramphistomum daubneyi could have been developed earlier in spring and later in the end of grazing season (32).

As regards to the Moniezia benedeni, the overall prevalence found in our investigation was much lower than that reported by Borthakur and Das (33) and Boucheikhchoukh et al. (18) (19.6\% vs. $1.93 \%$. $11.1 \%$. vs. $1.93 \%$, respectively). Young and pastured animals are more sensible to the monieziosis (34).
In the present study, coccidiosis is considered a major parasitosis as indicated by the relatively high prevalence in the overall examined animals (43.87\%). Achi et al. (19) reported a much lower prevalence of $9.9 \%$. The results of this experiment showed a high rate of infestation during the investigation period. According to Brian (35), the oocysts are very resistant and are active up to 18 months after discharge, especially when they undergo sporulation.

The proportion of infection causes by different parasitic species varied in the two age groups of cattle. It is the highest in aged animals and the lowest in young cattle. Studies have showed that the susceptibility and the pathogenicity of nematode infections are greater in young animals than in mature animals $(23,36,37)$. The immunity system of infected young animals is less developed at an early age (38). In contrast, the values of Moniezia benedeni and Paramphistomum daubneyi rates do not show a difference based on age, because the number of positive animal samples were too small to enable for an outstanding statistical analysis.

During the present study, a significantly higher proportion of young animals was infected with coccidian than was adult cattle $(\mathrm{P}<0.01)$. This result agrees with many reports from Kenya (37), Nigeria (39), South Africa (40) and the Netherlands (41). It is well known that clinical coccidiosis occurs mainly in young cattle (42). Note that the breeding conditions play an important role in the appearance of the parasitosis. Indeed, overcrowding, the animal mixture of various origins and poor hygiene are the risk factors for parasite infestation (43).

In the present research, the sampling population was female (heifer and cow) dominated (94.4\%) with only a few number of male cattle $(5.6 \%)$. The overall prevalence of cattle infected with Strongyle spp. and Eimeria spp. clearly shows a significant difference $(\mathrm{P}<0.01)$ between male and females. During lactation, the immune response of the host to gastrointestinal nematodes is partially suppressed leading to an increase in the population of worms (44). Other studies revealed a higher prevalence of nematodes in lactating and pregnant cows compared to bulls and oxen $(45,46)$. Pfukenvi and associated (46) has concluded that lactating and pregnant cows might serve as a potential source of pasture contamination. In the same way, Barger (5) explained that acquired immunity to nematodes infection tends to be lost in late pregnancy and in lactation.

In the literature, a combination of poor nutrition, high stocking rate and lack of anthelmintic 
medication are considered as the probable causes of the development of heavy worm burden in communally grazed cattle (47). The results obtained from thin cattle infected with Strongyle spp. could be explained by a dysfunction in the digestive tract. Indeed, infestation by digestive Strongyle causes enormous damage to the stomach and bad nutrition absorption of the cow as a reduction in motility and decrease of acid secretion (48). In addition, a recent study reported that the intensity of the symptoms of strongyloidiasis depends on the infestation degree, the animal age and the body condition (49). Also, toxocariasis causes physiological disorders in animal infested such as hypoglycemia, mineral deficiency.

Immature flukes aggravate injuries causing severe anemia syndromes (50). That could explain the high rates of thin animals infected with Fasciola hepatica. Note that Paramphistomum daubneyi parasite have a negative impact on the animal infected including poor diet absorption, growth delays, weight loss and diminution of milk production (51). The coccidiosis disease causes malabsorption intestinal and reduced production performance in animals (52). This could justify the significantly higher prevalence in thin animals than in obese ones.

\section{CONCLUSION}

In conclusion, our study demonstrated a high prevalence and the abundance of the polyparasitism nature of the disease in the Bass Kabylie area. Also, there was a relationship between the distribution of GI parasitism in cattle and the factors analyzed (body condition score, age and sex). Therefore, the parasitic fauna of each species, when mapped out accurately in such agro-climatic zones (Bass Kabylie), elucidates fundamental information, depending upon which further control measures can be followed.

\section{CONFLICT OF INTEREST STATEMENT}

The authors declare that they have no potential conflict of interest with respect to the authorship and/or publication of this article.

\section{ACKNOWLEDGEMENT}

The authors gratefully acknowledge Mr. Z. Bouzid and all staff of CAZAL (Bejaia, Algeria) for the help during the sampling in the bovine farm. The authors thank also veterinary colleagues A. Belharet and S. Benidiri for their hospitality and reception during his farm visits. The authors thank Dr. C. Harrats (University of Mostaganem, Algeria) for the English correction.

\section{REFERENCES}

1. Ministry of agriculture and rural development (MADR) (2012). Report on animal genetic resources, Algeria.

2. Borges, F. A., Almeida G. D., Heckler, R. P., Lemes, R.T., Onizuka, M.K.V., Borges, D. G. L. (2013). Anthelmintic resistance impact on tropical beef cattle productivity: effect on weight gain of weaned calves. Tropical Animal Health and Production 45, 723-727. https://doi.org/10.1007/s11250-012-0280-4 PMid:23076819

3. Mahusoon, M.M., Perera, A.N.F., Perera, E.R.K., Perera, K.A. (2004). Effect of molybdenum supplementation on circulating mineral levels, nematode infection and body weight in goats as related to season. Tropical Agricultural Research $16,128-136$.

4. Stromberg, B.E., Gasbarre, L.C., Waite, A., Bechtol, D.T., Brown, M.S., Robinson, N.A., Olson, E.J., Newcomb, H. (2012). Cooperia punctata: Effect on cattle productivity? Veterinary Parasitology 183, 284- 291.

https://doi.org/10.1016/j.vetpar.2011.07.030 PMid:21821358

5. Barger I.A., Gibbs, H.C. (1981). Milk production of cows infected experimentally with trichostrongylid parasites. Veterinary Parasitology 9, 69-73. https://doi.org/10.1016/0304-4017(81)90008-X

6. Mavrot, F., Hertzberg, H., Torgerson, P. (2015). Effect of gastro-intestinal nematode infection on sheep performance: a systematic review and metaanalysis. Parasites \& Vectors 8, 577-588.

https://doi.org/10.1186/s13071-015-1164-z PMid:26496893 PMCid:PMC4619485

7. Rahman, M.M., Samad, M.A. (2010). Prevalence of subclinical gastro-intestinal parasitosis and their effects on milk production with therapeutic management in red Chittagong cattle. Bangladesh Journal of Veterinary Medicine 8 (1): 11-16.

8. Ntonifor, H.N., Shei, S.J., Ndaleh, N.W., Mbunkur, G.N. (2013). Epidemiological studies of gastrointestinal parasitic infections in ruminants in Jakiri, Bui Division, North West Region of Cameroon. Journal of Veterinary Medicine and Animal Health 5 (12): 344-352. 
9. Baumgard, L.H., Rhoads, R.P., Rhoads, M.L., Gabler, N.K., Ross, G.B., Keating, A.F., Boddicker, R.L., Lenka, S., Sejian, V. (2012). impact of climate change on livestock production. In: Sejian, V., Naqvi, S.M.K., Ezji, T., Lakritz, J., Lal, R. (Eds.), Environmental stress and amelioration in livestock production (pp. 413-497). New York: Springer Dordrecht Heidelberg London.

https://doi.org/10.1007/978-3-642-29205-7

10. Keyyu, J.D, Kassuku, A.A, Msalilwa, L.P, Monradm J. and Kyvsgaad, N.C. (2006). Crosssectional prevalence of helminth infections in cattle on traditional, small-scale and large-scale dairy farms in Iringa district, Tanzania. Veterinary Research Communication 30, 45-55.

https://doi.org/10.1007/s11259-005-3176-1 PMid:16362610

11. Euzeby, J. (1982). Experimental diagnosis of animal helminthiases (domestic animals - laboratory animals - primates). In: Euzeby, J. (Ed.), Practical work in veterinary helminthology. Vol. II (pp. 295-322). Paris., Technical Information of Veterinary Services, Ministry of Agriculture.

12. Edmonson, A.J., Lean, I.J., Weaver, L.D., Farver, T., Webster, G. (1989). A body condition scoring chart for Holstein dairy cows. Journal of Dairy Science 72, 68-78.

https://doi.org/10.3168/jds.S0022-0302(89)79081-0

13. Cringoli, L. Rinaldi, V. Veneziano, G., Capelli, A. (2004). Scala the influence of floatation solution, sample dilution and the choice of McMaster slide area (volume) on the reliability of the McMaster technique in estimating the faecal egg counts of gastrointestinal strongyles and Dicrocoelium dendriticum in sheep. Veterinary Parasitology 123, 121-131.

https://doi.org/10.1016/j.vetpar.2004.05.021 PMid:15265576

14. Charles, P.D. (1996). Normal flora. In: Baron S. (Ed.), Medical Microbiology, 4th edition (pp. 70102). Texas, University of Texas Medical Branch at Galveston, Galveston.

15. Dimander, S.O.,Höglund, J., Uggla, A., Spörndlyn, E., Waller, P. J. (2003). Evaluation of gastro-intestinal nematode parasite control strategies for first season grazing cattle in Sweden. Veterinary Parasitology 111 (2-3): 193-209. https://doi.org/10.1016/S0304-4017(02)00380-1

16. Charlier, J., De Waele, V., Ducheyne, L., van der Voort, M., Vande Velde, F., Claerebout, E. (2016). Decision making on helminths in cattle: diagnostics, economics and human behaviour. Irish Veterinary Journal 69, 14-19.

https://doi.org/10.1186/s13620-016-0073-6 PMid:27708771 PMCid:PMC5039886
17. Fikru, R., Teshale, S., Reta, D., Yosef, K. (2006). Epidemiology of gastrointestinal parasites of ruminants in Western Oromia, Ethiopia. International Journal of Applied in Research Veterinary Medicine 4(1): 51-57.

18. Boucheikhchoukh, M., Righi, S., Sedraoui S., Mekroud, A., Benakhla, A. (2012). Main helminthoses cattle: epidemiological survey at two abattoirs in the region of El-Tarf (Algeria). Tropicultura 30 (3): 167-172.

19. Achi, Y.L., Zinsstag, J., Yéo, N., Dea,V., Dorchies, PH. (2003). Gastrointestinal nematodes of bovines in the savanna region of the Ivory Coast: slaughterhouse survey. Revue de Médecine Vétérinaire 154 (2): 105-112.

20. Agbajelola, V. I., Falohun Olufarati, O. (2015). Prevalence of intestinal helminths and protozoa parasites of ruminants in Minna, North Central, Nigeria. IOSR Journal of Agriculture and Veterinary Science 8(11): 62-67.

21. Lone, B.A., Chishti, M.Z., Ahmad F. (2013). Seasonal occurrence of gastrointestinal parasites in sheep of Kashmir division. International Journal of Livestock Research 3(2): 135-136. https://doi.org/10.5455/ijlr.20130509093410

22. Fuentes, M.V., Saez, S., Trelis, M., Galan-Puchades, M.T., Esteban, J.G. (2004). The helminth community of the wood, Apodemus sylvaticus, in the Sierra Espuna, Murda, Spain. Journal of Helminthology 78(2): 219-223.

https://doi.org/10.1079/JOH2003226

PMid:15469624

23. Beugnet, F., Guillot, J. (2008). General parasitic diseases: gastrointestinal strongyloses. In: Institutes breeding (Ed.), Cattle diseases. 4th edition (pp. 98105). Paris: France Agricole. PMCid:PMC2753212

24. Alcaraz, C.O., Adell, R.I., Sanchez, P.S., Blasco, M.J., Sanchez, O.A., Aunon, A.S. et al. (2004). Characteristics and geographical profile of strongyloidiasis in healthcare area 11 of the Valencian community (Spain). Journal of Infection 49, 152-158. https://doi.org/10.1016/j.jinf.2004.01.016 PMid:15236923

25. Macpherson C. N. (2013). The epidemiology and public health importance of toxocariasis: A zoonosis of global importance. International Journal for Parasitology 43, 999-1008. https://doi.org/10.1016/j.ijpara.2013.07.004 PMid:23954435

26. Aissi, M., Harhoura, KH., Gaid Hamrioui, S.B. (2009). Preliminary study on the prevalence of fascioliasis due to F. hepatica in some cattle farms of northern Algeria (Mitidja). Bulletin of Exotic Pathology Society 102, 177-178. 
27. Mrifeg, R., Belghyti, K., El kharrim, K., Laamri, M., Boukbal, M. (2012). Survey on bovine fascioliasis in the commune of khnichet (Morocco). World Journal of Biological Research 5 (1): 13-18.

28. Mekroud, A., Benakhla, A., Vignoles, P., Rondeleaud, D. (2004). Preliminary studies on the prevalences of natural fasciolosis in cattle, sheep, and the host snail Galba truncatula in north-eastern Algeria. Parasitology Research 92, 502-505. https://doi.org/10.1007/s00436-004-1072-1 PMid:14999466

29. Howell, A., Baylis, M., Smith, R., Pinchbeck, G., Williams, D. (2015). Epidemiology and impact of Fasciola hepatica exposure in high-yielding dairy herds. Preventive Veterinary Medecine 121 (1-2): 41-48.

https://doi.org/10.1016/j.prevetmed.2015.05.013

PMid:26093971 PMCid:PMC4528078

30. Lotfy, W.M., Brant, S.V., Ashmawy, K.I., Devkota, R., Mkoji, G.M., Loker E.S. (2010). A molecular approach for identification of paramphistomes from Africa and Asia. Veterinary Parasitology 174, 234-240.

https://doi.org/10.1016/j.vetpar.2010.08.027 PMid:20880634

31. Dinnik, J A, Dinnik, N. (1962). The growth of Paramphistomum microbothrium Fischoeder to maturity and its longevity in cattle. Bulletin of Epizootic Diseases of Africa 10, 27-31.

32. Okafor, F.C., Mbata, G., Anosike, J. (1988). Studies on Paramphistomum cervi (Schrank, 1790) infections of ruminants in Imo State, Nigeria with special reference to the role-played by Bulinus b. forskalii (Ehrenberg) in their transmission. Bulletin of Animal Health and Production in Africa 36, 142-146.

33. Borthakur, S.K., Das, M. (2005). Incidence of monieziosis in cattle and buffalo calves of Assam. Journal of Veterinary Parasitology 19 (2): 173174.

34. Beugnet, F., Polack, B., Dang, H. (2004). Coproscopy techniques. In: Beugnet F. (Ed.), Coproscopy atlas (pp 35-44). Clichy: Kalianxis.

35. Lasen, B. (2009). Epidemiological diagnosis and control of bovine coccidiosis in Estonia. Veterinary thesis, University of Natural Sciences of Eesti Maaülikool, Estonia.

https://dspace.emu.ee/xmlui/bitstream/handle/ 10492/127/Thesis Brian Lassen.pdf? sequence $=1$

36. Vassilev, G.D. (1999). Prevalence of internal parasite infections of cattle in the communal farming areas of Mashonaland east province, Zimbabwe. Zimbabwe Veterinary Journal 30, 1-17.
37. Waruiru, R.M., Kyvsgaard, N.C., Thamsborg, S.M., Nansen, P., Bøgh, H.O., Munyua, W.K., Gathuma, J.M. (2000). Prevalence and intensity of helminth and coccidial infections in dairy cattle in Central Kenya. Veterinary Research Communications 24, 39-53.

https://doi.org/10.1023/A:1006325405239 PMid:10703753

38. Dillard, K.J., Saari, S.A., Anttila, M. (2007). Strongyloides stercoralis infection in a Finnish kennel. Acta Veterinary Scandinavia 49, 37-42. https://doi.org/10.1186/1751-0147-49-37 PMid:18076758 PMCid:PMC2225404

39. Anene, B.M., Onyekwodiri, E.O., Chime, A.B., Anika, S.M. (1994). A survey of gastrointestinal parasites in cattle of southeastern Nigeria. Preventive Veterinary Medicine 20, 297-306. https://doi.org/10.1016/0167-5877(94)90062-0

40. Matjila, P.T., Penzhorn, B.L. (2002). Occurrence and diversity of bovine coccidia at three localities in South Africa. Veterinary Parasitology 104, 93-202. https://doi.org/10.1016/S0304-4017(01)00605-7

41. Cornelissen, A.W.C.A., Verstegen, R., Van Den Brand, H., Perie, N.M., Eysker, M., Lam, T.J.G.M., Pijpers A. (1995). An observational study of Eimeria species in housed cattle on Dutch dairy farms. Veterinary Parasitology 56, 7-16. https://doi.org/10.1016/0304-4017(94)00671-X

42. Munyua, W.K., Ngotho, J.W. (1990). Prevalence of Eimeria species in cattle in Kenya. Veterinary Parasitology 15, 163-168. https://doi.org/10.1016/0304-4017(90)90126-V

43. Dorchies P., Duncan J., Losson B., Alzieu J.P. (2012). Parasitic diseases inducing digestive disorders (Protozooses). In: MED'COM (Ed.), Vademecum of clinical parasitology of cattle (pp. 342-421). Paris: Med'Com.

PMCid:PMC3353109

44. Connan, R.M. (1976). Effect of lactation on the immune response to gastrointestinal nematodes. Veterinary Record 99, 76- 477.

https://doi.org/10.1136/vr.99.24.476

45. Hammerberg, B., Lamm, W.D. (1980). Changes in periparturient faecal egg counts in beef cows calving in the spring. American Journal of Veterinary Research 41, 1686-1689.

PMid:7224299

46. Pfukenyi, D.M., Mukaratirwa, S., Willingham, A.L., Monrad, J. (2007). Epidemiological studies of parasitic gastrointestinal nematodes, cestodes and coccidia infections in cattle in the highveld and Lowveld communal grazing areas of Zimbabwe. Onderstepoort Journal of Veterinary Research 74, 129-142. https://doi.org/10.4102/ojvr.v74i2.132 
47. Pandey, V.S., Chitate, F., Nyanzunda, T.M. (1993). Epidemiological observations on gastro-intestinal nematodes in communal land cattle from the highveld of Zimbabwe. Veterinary Parasitology 51, 99-106.

https://doi.org/10.1016/0304-4017(93)90200-7

48. Niranjan, K. Thakur, K. Sh. R., Anju, V., Veer Singh, R. (2013). Internal parasite management in grazing livestock. Journal of Parasitic Disease 37 (2): $151-157$. https://doi.org/10.1007/s12639-012-0215-Z PMid:24431559 PMCid:PMC3793100

49. Rahmann, G., Seip, H. (2007). Alternative management strategies to prevent and control endo-parasite diseases in sheep and goat farming systems-a review of the recent scientific knowledge. Landbauforschung Völkenrode 57, 75-88.
50. Cheepsattayakorn, A., Cheepsattayakorn, R. (2014). Parasitic pneumonia and lung involvement. Biomed Research International 1-18.

https://doi.org/10.1155/2014/874021

PMid:24995332 PMCid:PMC4068046

51. Alzieu, J.P., Dorchies, P. (2007). Reemergence of cattle paramphistomiasis in France: current review of epidemiology, pathophysiology and diagnosis. Bulletin of Academy Veterinarian of France 160 (2): 93-99.

https://doi.org/10.4267/2042/47872

52. Schelcher, F., Guillot, J. (2008). General parasitic diseases: Coccidiosis bovine disease. In: institutes breeding (Ed.), Cattle diseases 4th edition (pp. 131135). Paris: France Agricole. 